\title{
The Unconstitutionality of Limitations on Contributions to Political Committees in the 1976 Federal Election Campaign
}

Act Amendments

The Supreme Court's decision in Buckley v. Valeo ${ }^{1}$ partially dismantled the electoral reform program formulated in the 1974 Amendments to the Federal Election Campaign Act of 1971.2 The Court declared that the Act's limitations on expenditures by candidates and independent expenditures in federal elections unconstitutionally burdened political speech and association, while it upheld restrictions on contributions to candidates.

After five months of deliberation, Congress attempted to salvage its design for electoral reform by enacting the Federal Election Campaign Act Amendments of $1976 . .^{3}$ Responding to Buckley's approval of restrictions on political contributions, Congress imposed new limits on "contributions" to political committees." This Note argues that, under the framework of analysis employed by the Court in Buckley, the 1976 Amendments' limitations on contributions to political committees are unconstitutional.

\section{The 1976 Federal Election Campaign Act Amendments}

The 1976 Amendments impose various limits on contributions by persons $s^{\sqrt{5}}$ to federal candidates. The Act defines "contribution" broadly

1. 424 U.S. 1 (1976) (per curiam). Buckley v. Valeo has received much attention in the legal literature. E.g., Clagett \& Bolton, Buckley v. Valeo, Its Aftermath, and Its Prospects: The Constitutionality of Government Restraints on Political Campaign Financing, 29 Vand. L. REv. 1327 (1976); Wright, Politics and the Constitution: Is Money Speech?, 85 YALE L.J. 1001 (1976); Young, Supreme Court Report, 62 A.B.A.J. 362, 362-63 (1976); The Supreme Court, 1975 Term, 90 HARv. L. Rev. 58, 171-96 (1976); Comment, Buckley v. Valeo: The Supreme Court and Federal Campaign Reform, 76 Colum. L. REv. 852 (1976); Comment, The Constilutionality of Limitations on Individual Political Campaign Contributions and Expendilures: The Supreme Court's Decision in Buckley v. Valeo, 25 EMORY L.J. 400 (1976); Comment, Campaign Finance in Wisconsin After Buckley, 1976 Wis. L. Rev. 816.

2. Federal Election Campaign Act Amendments of 1974, Pub. L. No. 93-443, [1974] U.S. Code Cong. \& An. News 1436 (88 Stat. 1263) (amending Federal Election Campaign Act of 1971, Pub. L. No. 92-225, 86 Stat. 3 (1972)).

3. Federal Election Campaign Act Amendments of 1976, Pub. L. No. 94-283, [1976] U.S. Code Cong. \& Ad. News (90 Stat. 475).

4. 2 U.S.C.A. $\$ 441 \mathrm{a}(\mathrm{a})(\mathrm{I})(\mathrm{C})$, (2)(C) (West Cum. Supp. 1977).

5. The term "person" includes "an individual, partnership, committee, association, corporation, labor organization, and any other organization or group of persons." Id. $\$ 431(\mathrm{~h})$; see Federal Election Commission (FEC) Proposed Regulation $\$ 100.13$, 41 Fed. 
to include disbursements of money and transfers of things of value for the purpose of influencing federal elections. ${ }^{6}$ Individuals, political committees and associations may contribute no more than $\$ 1,000$ per election "to any candidate and his authorized committees." $7 \mathrm{~A}$ "multicandidate political committee" 8 may contribute a total of $\$ 5,000$ per candidate per election. ${ }^{9}$

The 1976 Amendments also restrict contributions to political committees not authorized by a federal candidate. Contributions to political committees "established and maintained" by a national political party may not exceed $\$ 15,000$ from any multicandidate committee or $\$ 20,000$ from any other person. ${ }^{10}$ Furthermore, no individual or organization may give more than $\$ 5,000$ per year "to any other political committee."11 Finally, the Amendments limit total contributions to candidates and committees by any individual to $\$ 25,000$ per calendar year. ${ }^{12}$

This Note scrutinizes the restrictions upon contributions to political committees. A "political committee" is defined statutorily as "any committee, club, association, or other group of persons which receives contributions or makes expenditures during a calendar year in an aggregate amount exceeding $\$ 1,000 . " 13$ This Note also focuses upon the annual $\$ 25,000$ ceiling for all contributions by an individual. The 1976 Amendments use no terms to distinguish contributions made to a candidate from contributions made to a political committee. For the

Reg. 35932, 35937 (1976) (to be codified in 11 C.F.R. $\$ \S 100.1-146.1$ ) [hereinafter cited without cross-reference as Regulation]. The Proposed Regulations were made final, with minor amendments, by an FEC announcement on April 13, 1977, after a 30-day Congressional review period. 42 Fed. Reg. 19324 (1977).

6. 2 U.S.C.A. $\$ 431$ (e) (WVest Cum. Supp. 1977).

7. 2 U.S.C.A. \$ 441a(a)(1)(A) (West Cum. Supp. 1977); see Regulation $\$ 110.1$ (a)(1). The FEC interprets a candidate's "authorized committee" to be a "political committee which is empowered in writing by a candidate to solicit or receive contributions or make expenditures on behalf of the candidate," or whose activity on his behalf has not been disavowed. Id. $\S 100.14(\mathrm{~b})(1)$.

8. A "multicandidate political committee" is a "political committee which has been registered ... for a period of not less than 6 months, which has received contributions from more than 50 persons, and, except for any State political party organization, has made contributions to 5 or more candidates for Federal office." 2 U.S.C.A. $\$ 441 a(a)(4)$ (West Cum. Supp. 1977); see Regulation § 100.14(a)(3).

9. 2 U.S.C.A. $\$ 441 \mathrm{a(a)(2)(A)} \mathrm{(West} \mathrm{Cum.} \mathrm{Supp.} \mathrm{1977);} \mathrm{see} \mathrm{Regulation} \$ 110.2(\mathrm{a})(1)$.

10. 2 U.S.C.A. $\$ 441 \mathrm{a}(\mathrm{a})(2)(\mathrm{B})$, (1)(B) (West Cum. Supp. 1977); see Regulation $\$ \S$ $110.2(a)(2), 110.1(b)(4)$. For purposes of these sections, the FEC defines "political committees established and maintained by a national political party" as (I) the national committee; (2) the House campaign committee; and (3) the Senate campaign committee." Id. $\$ \S 110.1(\mathrm{~b})(2), 110.2(\mathrm{a})(2)(\mathrm{ii})$.

11. 2 U.S.C.A. § $441 \mathrm{la}(\mathrm{a})(\mathrm{I})(\mathrm{C}),(2)(\mathrm{C})$ (West Cum. Supp. 1977); see Regulation $\$ \$ 110.1$ (c), $110.2(\mathrm{a})(3)$.

12. 2 U.S.C.A. $\$ 441 a(a)(3)$ (West Cum. Supp. 1977); see Regulation $\$ 110.5(a)$.

13. 2 U.S.C.A. $\$ 431$ (d) (West Cum. Supp. 1977); see Regulation $\$ 100.14$. 
sake of analysis, gifts of money or anything of value to a candidate or his authorized committees and agents will be referred to as "candidate contributions"; gifts or transfers to unauthorized political committees, both party and nonparty, will be referred to as "donations."

\section{Political Spending and First Amendment Values}

\section{A. Buckley's Classification: Contributions and} Independent Expenditures

The legislation confronting the Buckley Court was similar to the 1976 Amendments. The 1974 Amendments imposed the same $\$ 1,000$ and $\$ 5,000$ limitations upon contributions to a candidate ${ }^{14}$ and restricted total annual contributions by an individual to $\$ 25,000 .^{15}$ In addition, the 1974 Act placed a ceiling of $\$ 1,000$ per year upon "independent expenditures" made "relative to a clearly identified candidate." 16

The Buckley Court upheld the contribution limitations of the 1974 Act, but struck down the limits imposed upon independent expenditures. ${ }^{17}$ Its analysis of the provisions began by distinguishing the First Amendment values implicated by the acts of contributing and spending independently. ${ }^{18}$ The Court recognized that both contributions and independent expenditures constitute forms of expression that come within the free speech guarantee of the First Amendment. The act of contributing communicates the contributor's general support for the recipient candidate. ${ }^{19}$ Similarly, the independent spender expresses his political beliefs by advocating the election or defeat of a clearly identified candidate. ${ }^{20}$ Furthermore, both contributions and independent expenditures are forms of political association. A contribution or an independent expenditure made relative to a candidate affiliates the contributor or spender with that candidate. ${ }^{21}$

Nevertheless, the court found fundamental differences in the expressive and associational properties of contributions and independent

14. Compare 18 U.S.C. $\$ 608(\mathrm{~b})(\mathrm{I})$ (Supp. V 1975) (repealed 1976) with 2 U.S.C.A. $\S 441 \mathrm{a}(\mathrm{a})(1)(\mathrm{A})$ (West Cum. Supp. 1977) (\$1,000 limit); compare 18 U.S.C. $\$$ 608(b)(2) (Supp. V 1975) (repealed 1976) with 2 U.S.C.A. $\$ 441 a(a)(2)(A)$ (West Cum. Supp. 1977) (\$5,000 limit).

15. Compare 18 U.S.C. $\S 608(b)(3)$ (Supp. V 1975) (repealed 1976) with 2 U.S.C.A.

$\S 441 a(a)(3)$ (West Cum. Supp. 1977).

16. I8 U.S.C. $\$ 608$ (e) (Supp. V 1975) (repealed 1976).

17. See 424 U.S. 1, 58-59 (1976) (per curiam).

18. See id. at 19-23.

19. Id. at 21.

20. See id. at $39,40,48$.

21. Id. at 22. 
expenditures. The Buckley Court concluded that contributions function merely as vicarious speech. ${ }^{22}$ Although a contribution may symbolize the contributor's support for a candidate, it does not articulate precisely the political sentiments or opinions underlying the gift. Only in the hands and at the behest of the recipient candidate will such articulate expression be realized. ${ }^{23}$ As symbolic speech, a contribution's expressive capacity "does not increase perceptively with [its] size." At most, contribution restrictions inhibit only the demonstration of the intensity of a contributor's support; they do not affect the contributor's freedom to discuss candidates and issues. ${ }^{25}$ Furthermore, although contribution ceilings curb one important means of associating with a candidate or a committee, they leave untrammeled the right of membership and active participation in an association and do not hinder the ability of candidates and associations to gather large sums of money for effective advocacy. ${ }^{26}$ Ceilings on contributions, then, do not significantly curtail the contributor's individual expression and association, the core values of the First Amendment.

The Buckley Court described an independent expenditure, on the other hand, as a means of facilitating the spender's own political speech. ${ }^{27}$ Therefore, limitations upon independent expenditures directly restrict the degree to which the spender can speak autonomously. Particularly because of " $[t]$ he electorate's increasing dependence on television, radio, and other mass media for news and information," 28 any exacting restriction necessarily burdens use of the most effective forms of political expression. ${ }^{29}$

Limits on independent expenditures also impinge on freedom of association. The Act's restrictions applied to organizations as well as individuals, and thus constrained an organization's ability to spend resources for its members' political expression. The independent expenditure ceiling, the Court held, "precludes most associations from effectively amplifying the voice of their adherents, the original basis for the recognition of First Amendment protection of the freedom of association." 30

22. Id. at 21 .

23. Id.

24. Id.

25. Id.

26. Id. at 22 .

27. Id. at 19-20, 39. The Court provided an illustration of an expenditure made "relative to a clearly identified candidate" as a single one-quarter page advertisement which a person or association might place in a major metropolitan newspaper to advocate a particular candidate's election. $I d$. at 40 .

28. Id. at 19.

29. Id. at $19-20$.

30. Id. at 22 . 


\section{B. Donations: $A$ Third Classification}

By classifying disbursements or transfers to unauthorized political committees (donations) $)^{31}$ as "contributions," the 1976 Amendments draw these transactions into the category of spending constitutionally regulated under the 1974 Amendments. ${ }^{32}$ Congress, however, may not regulate political campaign activities as it chooses by the mere use of labels. To be sure, donations can be distinguished from independent expenditures in form: the independent spender speaks for himself whereas the donor does not directly finance expression. Yet, this does not compel the classification of donations as contributions. The constitutional significance of donations turns upon the strength of the First Amendment values attached to this mode of expression and association. Analysis must begin, as in Buckley, with the recognition of the burden on core First Amendment rights imposed by restrictions on donations.

Buckley acknowledged that "the original basis for the recognition

31. An analysis of donations immediately must exclude contributions to any committee authorized by a candidate or unauthorized but acting as an intermediary or a conduit on behalf of a candidate. These are regarded correctly under the Act and FEC regulations as indirect contributions to a candidate. See pp. 968-69 infra.

32. One might argue that donations constitute "expenditures" within the meaning of 2 U.S.C.A. $\$ 431$ (f) (West Cum. Supp. 1977), rather than "contributions." So classified, donations would not be subject to the $\$ 5,000$ limit on "contributions" to political committees. See id. $\$ 441 \mathrm{a}(\mathrm{a})(\mathrm{I})(\mathrm{C})$, (2)(C).

This interpretation, however, is inconsistent with statutory language and Congressional intent. First, donations clearly come within the statutory definition of "contribution" as gifts of money or anything of value made to influence federal elections. Id. $\$ 431$ (e). Were donations construed to be "expenditures," the provisions in the 1976 Amendments restricting "contributions" to political committees would be rendered meaningless and totally inoperative.

Second, the uses of the words "contribution" and "expenditure" throughout the Act argue against this interpretation. Contributions are viewed as payments or transfers that permit the recipient to control the future purposes and applications of the funds. Expenditures, on the other hand, connote direct purchases of goods or services for political campaigns, purchases which are controlled by the spender. With this taxonomy, donations must be viewed as contributions to a political committee which the committee uses to make expenditures. The statutory definitions of contributions and expenditures overlap to some extent, but there are revealing differences. Whereas the definition of "contribution" incudes "a gift, subscription, loan ... of money or anything of value," id. $\S 431$ (e)(1), the term "expenditure" designates "a purchase, payment, distribution ... of money or anything of value." Id. $\$ 431(\mathrm{f})(\mathrm{I})$.

Other provisions seem to treat donations as contributions. A political committee is defined as an entity "which receives contributions or makes expenditures during a calendar year in an aggregate amount exceeding $\$ 1,000 . " I d$. $\$ 431$ (d). Similarly, the Act requires a political committec treasurer to account for "all contributions made to or for such committee" and "all expenditures made by or on behalf of such committee" but does not mention cxpenditures made to such committee. Id. $\$ 432(\mathrm{c})(1),(3)$. Furthermore, political committee reports must disclose "the total sum of individual contributions made to or for such committee ... during the reporting period," id. $\S 434(\mathrm{~b})(3)$, and "the total sum of expenditures made by such committee," id. $\$ 434(\mathrm{~b})(9)$. 
of First Amendment protection of the freedom of association" was the function of political committees in "effectively amplifying the voice of their adherents." ${ }^{33}$ The Court relied on Sweezy $v$. New Hampshire ${ }^{34}$ and NAACP v. Alabama ex. rel. Patterson, ${ }^{35}$ the first of a line of precedents that established an individual's First Amendment right to effective political speech through participation in an effective political organization. ${ }^{36}$ Since NAACP $v$. Alabama, it is an established constitutional tenet that a political party committee or any other political committee "is but the medium through which its individual members seek to make more effective the expression of their own views." ${ }^{37}$ In essence, the collective expression of a political committee, existing as the aggregate of its members, is the extension of the individual speech of its members. ${ }^{38}$

33. 424 U.S. at 22.

34. 354 U.S. 234 (1957) (plurality opinion). Stweezy recognized: "Our form of government is built on the premise that every citizen shall have the right to engage in political expression and association. . . Exercise of these basic freedoms in America has traditionally been through the media of political associations." Id. at 250 .

35. 357 U.S. 449 (1958).

36. See, e.g., Kusper v. Pontikes, 414 U.S. 51 (1973) (Illinois statute which prohibits person from voting in a primary of a political party if he has voted in primary of another party within preceding 23 months violates right to associate effectively with political party of one's choice); NAACP v. Button, 371 U.S. 415 (1963) (Virginia statute prohibiting NAACP from urging blacks to seek legal redress for violation of their civil rights unjustifiably invades the First Amendment rights of the NAACP's members); Bates v. City of Little Rock, 361 U.S. 516 (1960) (local ordinances requiring disclosure of NAACP membership lists impermissibly burdens free association).

37. 357 U.S. at 459. Justice Rutledge's concurring opinion in United States v. CIO, 335 U.S. 106, 143-44 (1948), described the "guaranty of freedom of assembly" as

a liberty essentially coordinate with the freedoms of speech, the press, and conscience.

... It is not by accident, it is by explicit design, ... that these freedoms are coupled together in the First Amendment's assurance. They involve the right to hear as well as to speak, and any restriction upon either attenuates both.

There is therefore an effect in restricting expenditures for the publicizing of political views not inherently present in restricting other types of expenditure, namely, that it necessarily deprives the electorate, the persons entitled to hear, as well as the author of the utterance, whether an individual or a group, of the advantage of free and full discussion and of the right of free assembly for that purpose. 38. See Buckley v. Valeo, 424 U.S. 1, 22 (1976) (per curiam); NAACP v. Alabama $e x$ rel. Patterson, 357 U.S. 449, 460-61 (1958) (effective adrocacy of both public and private viewpoints undeniably enhanced by association). Professor Thomas I. Emerson asserts:

$[\mathrm{I}] \mathrm{t}$ is clear from the functions served by association in a democratic society that associational expression should be entitled to the same complete protection as individual expression. Organization primarily supplies the mechanism for reaching a wider audience. It does not change the character of expression as the communication of beliefs, opinions, information and ideas, or its content. Thus associational expression is simply an extension of the individual right of expression and, for the same reasons and to the same extent, should be free of governmental abridgment.

T. EMERson, The System of Freedom of Expression 432 (1970). The Supreme Court's opinion in Griswold v. Connecticut, 381 U.S. 479, 483 (1965) (dictum), essentially adopts Professor Emerson's position. The right of association, it explains, is more than the right to attend a meeting; it includes the right to express one's 
The nature of collective expression does not support Congress's denomination of donations as "contributions." Disregarding the potential for symbolic communication, a contribution's expressive value will be realized by someone other than the contributor. A donation, however, involves the donor's own speech. The donor does not give money in order that someone else speak; he constitutes a part of that which is speaking.

Naturally, the extent to which the expression of a political committee can be identified as the speech of a particular donor depends upon the size and organizational structure of the particular committee and the donor's relationship to the committee. Where $\mathrm{X}$ and $\mathrm{Y}$ organize a "Committee of Two" to make independent expenditures toward purchasing newspaper space for advertisements that they have jointly written and signed, the committee's expression clearly constitutes the speech of $\mathrm{X}$ and $\mathrm{Y} .{ }^{30}$ This equivalence weakens, however, as the political committee acquires an impersonal, bureaucratic identity of its own, and as the donor is further removed from its governing center.

But even with larger, formally structured committees, association may conceivably be the single available means for certain persons to speak effectively. If the electorate's dependence on mass media for

attitudes or philosophies by membership in a group or by affiliation with it. . . Association in that context is a form of expression of opinion; and while it is not expressly included in the First Amendment its existence is necessary in making the express guarantees fully meaningful.

39. The two-person independent spending committee is not hypothetical; the FEC's files include several examples. For instance, two women formed the "Ad Hoc Committee Concerned for Life" in order to place an advertisement in the Long Island Catholic supporting Senator James Buckley. The committee's letter to the FEC stated that the advertisement cost $\$ 660$ and "was not authorized by Senator Buckley or any political committee associated with him." Letter from Patricia Corry and Carolyn Dlugozima to Federal Election Commission (Oct. 26, 1976) (FEC microfilm location 76FEC/037/1692). Similarly, four Californians contributed $\$ 1,103.68$ to the Mid-Peninsula Environmentalists for Carter Committee which spent the funds for advertisements in local newspapers. Letter from Robert Girard to Federal Election Committee (Dec. 2, 1976) (FEC microfilm location 76FEC/044/0972). For other examples of small independent spending committees, see, e.g., Report of Independent Expenditures or Contributions By Persons, FEC Form filed by Daniel Patrick Moynihan for Senate (Jan. 10, 1977) (FEC microfilm location 77FEC/046/1719) (30 persons donate total of $\$ 699$ expended for several local newspaper and radio advertisements); Report of Independent Expenditures or Contributions By Persons, FEC form filed by Young Business and Professional Men \& Women for President Ford (Nov. 2, 1976) (FEC microfilm location $76 \mathrm{FEC} / 038 / 1085)$ ( 80 donors; donations range from S1 to \$25); Letter from Hal F. Broughton, Chairman, Concerned Oregon Citizens Committee to Federal Election Commission (Oct. 29, 1976) (FEC microfilm location 76FEC/038/0031) (single \$2,322 expenditure for newspaper advertisement); Letter from Vernon Stout, Chairman, Hughes County Voters Interested in the Peace, Freedom, and Prosperity of Our Country 3 to Federal Election Commission (Jan. 7, 1977) (FEG microfilm location 77FEC/045/2380) (five donations totaling \$125.16 expended for single advertisement in Holdenville, Oklahoma, daily newspaper). 
campaign news and information has, in fact, made these modes of political communication indispensable, ${ }^{40}$ then the collective voice may be essential, especially in large metropolitan areas where television time or newspaper space is expensive. ${ }^{41}$ It has been suggested that persons who cannot afford bold political advertisements may refrain entirely from independent speech, deciding that weak expressive impact cannot justify any expense. ${ }^{42}$ Moreover, the packaging of a political advertisement is as important to the speaker's message as the eloquence of the written word. ${ }^{43}$ Thus, even where money is not a concern, lack of literary talent or the time necessary to create and disseminate autonomous speech may discourage independent expenditures. Depending upon these conditions and others, such as availability of media outlets and the size of the audience, persons may decide that donations to those committees espousing their political beliefs, although not as personal a form of expression as independent expenditures, will alone "speak" with consequence. ${ }^{44}$ Limits on donations therefore may stifle the effective expression of those who lack sufficient monetary or personal resources. Furthermore, ceilings on individual donations to committees directly obstruct the committees' purpose in "effectively amplifying the voice of their adherents" 45 insofar as their expressive capacity depends upon donations from their supporters.

Therefore, donations to political committees do not fit precisely

40. Buckley v. Valeo, 424 U.S. 1, 19 (1976) (per curiam).

41. For example, the Buckley Court noted that, as of January 1, 1975, one full-page advertisement in a daily edition of a certain metropolitan newspaper cost $\$ 6,971.04$. Id. at 20 n. 20 .

42. Hollihan, The Federal Election Campaign Act Amendments of 1974: The Constitutionality of Limiting Political Advertising by the Non-Candidate, 3 FLA. ST. U.L. REv. 266,283 (1975).

43. The Supreme Court has noted that effective speech serves "a dual communicative function," conveying both "ideas capable of relatively precise, detached explication," as well as "otherwise inexpressible emotions." Cohen v. California, 403 U.S. 15, 26 (1971) (state may not, consistently with the First and Fourteenth Amendments, make the mere public display of an expletive a criminal offense). A message's cognitive and emotive force depends upon the manner in which it is transmitted. Cf. Tinker v. Des Moines Independent Community School Dist., 393 U.S. 503 (1969) (wearing black armbands in opposition to Viet Nam war).

44. The fact that collective political advocacy often proves more feasible and influential than autonomous speech was underscored in Pollard v. Roberts, 283 F. Supp. 248, 258 (E.D. Ark.), aff'd per curiam, 393 U.S. 14 (1968) (prosecutor's attempt to compel disclosure of contributors to Republican campaign fund violated associational rights of contributors):

For better or for worse, the only means, apart from voting, whereby most people can participate effectively in politics is to affiliate themselves with a political party and to make financial contributions thereto according to their respective means and inclinations.

45. Buckley v. Valeo, 424 U.S. 1, 22 (1976) (per curiam). 
Buckley's characterization of either independent expenditures or contributions. Arguably, the First Amendment accords stronger protection to donations than it does to candidate contributions, because donations to political committees bind up varying degrees of individual speech with association. Under the analysis of Buckley, their regulation burdens core First Amendment values more severely than do contribution limitations. Yet, donations do not implicate these values to the same extent as totally autonomous expression through independent expenditures. Rather, donations must be considered as a third classification. When examining the First Amendment protection that ought to be extended to donations, they must be analyzed on their own terms. Congress cannot ensure the constitutionality of its limits on donations simply by labeling donations "contributions."

III. The 1976 Amendments and the First Amendment

\section{A. Strict Scrutiny under Buckley v. Valeo}

The Buckley Court explicitly applied strict standards in scrutinizing the limitations on contributions and independent expenditures in the 1974 Amendments. The Court held that contributions constitute one important aspect of association, ${ }^{46}$ and that "governmental 'action which may have the effect of curtailing the freedom to associate is subject to the closest scrutiny." " 47 Similarly, the constitutionality of the independent expenditure restriction turned "on whether the governmental interests advanced in its support satisfy the exacting scrutiny applicable to limitations on core First Amendment rights of political expression." 48

Although the Court noted that the Act's "expenditure ceilings impose significantly more severe restrictions on protected freedoms of political expression and association than do its limitations on financial contributions," 49 it did not develop two distinct tests or levels of scrutiny by which to judge the restrictions. ${ }^{50}$ After identifying First

46. Id.

47. Id. at 25 (quoting NAACP v. Alabama ex rel. Patterson, 357 U.S. 449, 460-61 (1958)).

48. Id. at $44-45$.

49. Id. at 23 .

50. It has been suggested erroneously that in Buckley $v$. Valeo the Court developed and applied two distinct scrutiny tests to examine the state interests for regulating contributions and independent expenditures. See The Supreme Court, 1975 Term, 90 Harv. I.. REv. 56, 178-79 (1976). Were the editors of the Harvard Law Review correct in their analysis of Buckley, the burdens upon First Amendment rights imposed by limitations on donations, see pp. 959-60 supra, would justify use of the stricter test. 
Amendment infringement sufficient to trigger strict scrutiny, the Court determined, first, whether substantial governmental interests existed for regulation. If they existed, the Court then looked to whether the regulatory provisions directly and narrowly served these interests. Finally, the Court inquired whether the government's objectives could not be achieved by other means that intruded less upon First Amendment values. Only by satisfying all three stages could the challenged restrictions be sustained.

\section{Candidate Contributions}

The Court found that "the Act's primary purpose"-to limit the actuality and appearance of quid pro quo arrangements between a contributor and a candidate-constituted a substantial governmental interest in contribution limitations. ${ }^{.1}$ The Court observed that corruption caused by a candidate's dependence upon the support of contributors to launch expensive campaigns undermines the integrity of American representative democracy. ${ }^{52}$ The appearance of corruption, arising from the public awareness of the opportunities for abuse, erodes confidence in the representative system. ${ }^{53}$ Thus, the Court held that Congress's interests in stemming the reality and semblance of quid pro quo abuse were substantial. 54

Moreover, the Act's regulatory "means" centered directly and narrowly upon the government's "ends." Restrictions on contributions focused "precisely upon the problem of large campaign contributionsthe narrow aspect of political association where the actuality and potential for corruption have been identified." ${ }^{5 s}$ Clearly, ceilings on

51. 424 U.S. at 26. The Buckley Court indicated that it was "unnecessary to look beyond the Act's primary purpose . . . in order to find a constitutionally sufficient justification for the $\$ 1,000$ contribution limitation." Id. The Court noted, however, two "ancillary" interests asserted by the state to justify the contribution limitations: equalizing the financial "voice" of all citizens in the electoral process and braking the "skyrocketing" cost of political campaigns. Id. at 25-26. Only in its discussion of the independent expenditure limitation did the Court consider the constitutional legitimacy of these "ancillary" purposes for restriction of financial political activity. The Court authoritatively rejected the first reason because "the concept that government may restrict the speech of some elements of our society in order to enhance the relative voice of others is wholly foreign to the First Amendment." Id. at 48-49. Regarding the second rationale, the Court held that "the mere growth in the cost of federal election campaigns in and of itself provides no basis for governmental restrictions on the quantity of campaign spending and the resulting limitation on the scope of federal campaigns." Id. at 57. Therefore, the sole governmental interest for regulation of either contributions or independent expenditures that the Court recognized as substantial was the prevention of quid pro quo corruption between a contributor and a candidate.

52. Id. at 25-27.

53. Id. at 27.

54. Id. at 29 .

55. Id. at 28. 
contributions mitigate the potential for actual quid pro quo corruption. The Court did not assume that all large contributors seek improper influence over a future officeholder; ${ }^{\mathbf{5} 6}$ it recognized that contribution limitations may prove somewhat overinclusive as a means of stemming actual abuse. But the Court concluded that the statute was not overbroad because it furthered the legitimate objective of reducing the appearance of corruption: a limit on contributions dispels "the appearance of impropriety" by eliminating the opportunity for corruption "inherent in the process of raising large monetary contributions."

Applying the third tier of scrutiny, the Court did not find less intrusive alternative means to achieve the government's objectives. Criminal laws prohibiting bribery fall short in stemming actual corruption because they are effective against "only the most blatant and specific attempts of those with money to influence governmental action." 58 Furthermore, the Court accepted Congress's conclusion that disclosure obligations deal inadequately with the reality or appearance of electoral abuse. ${ }^{59}$ Therefore, regulation of contributions to candidates met Buckley's strict scrutiny standards. ${ }^{\circ 0}$

\section{Independent Expenditures}

In contrast, the independent expenditure ceiling could not be justified. The restraint did clear the first barrier in Buckley's strict scrutiny test. The Supreme Court acknowledged Congress's intent to "maximiz[e] the effectiveness of the ... contribution limitations" by restricting independent expenditures. ${ }^{61}$ The provision purported to close loopholes through which spending on a candidate's behalf might be made with the semblance of independence. ${ }^{62}$ Insofar as "loophole

56. Id. at 29.

57. Id. at 29-30.

58. Id. at $27-28$.

59. Id. at 28 .

60. The Court also upheld the $\$ 25,000$ ceiling on total contributions by an individual in a calendar year as "no more than a corollary of the basic individual contribution limitation." Id, at 38 ; see pp. 971.73 infra.

61. 424 U.S. at 44.

62. The Court of Appeals for the District of Columbia, after alluding to evidence of widespread circumvention of the 1974 Amendments' contribution limits by many "independent committees," had upheld the independent cxpenditure limitation as "a necessary and constitutional means of closing a loophole that would otherwise destroy: the effectiveness" of the individual contribution restrictions. Buckley v. Valeo, 519 F.2d 821,853 (D.C. Cir. 1975), aff'd in part and rev'd in part, 424 U.S. 1 (1976) (per curiam). The court gave credence to the government's argument that "[a]n expenditure may obviously inure to the benefit of a candidate even though . . . the candidate was not in control of the expenditure or of the goods or services purchased." Id. at 852-53. 
closing" aimed to prevent actual or apparent corruption, regulation of independent expenditures supported a substantial governmental purpose, ${ }^{, 3}$ the "primary interest served . . . by the Act as a whole." 04

The independent expenditure limitation failed, however, to focus directly and narrowly upon elimination of such abuse. The Court found that the ceiling suffered from gross overbreadth. First, the restriction was clearly unnecessary as a means of reaching potentially corruptive spending on behalf of a candidate, such as expenditures controlled by or coordinated with a candidate or his campaign committee. The Court interpreted the 1974 Amendments to treat these expenditures as contributions to that candidate, rather than as independent expenditures. ${ }^{65}$ Second, the restriction burdened political activity which has little corruptive potential. Independent expenditures, by their lack of prearrangement or coordination, do not have "virtually the same value to the candidate" as a contribution. ${ }^{66}$ Where the spender speaks himself, his expenditures "may well provide little assistance to the candidate's campaign and indeed may prove counterproductive." 67 The absence of an actual candidate-contributor relation "alleviates the danger that expenditures will be given as a quid pro quo for improper commitments from the candidate." 08 The lack of a visible associational link vitiates the appearance of corruption.

The Court also found the independent expenditure limitation to be unconstitutionally underinclusive. In order to avoid impermissible vagueness, the Court construed the provision "to apply only to expenditures for communications that in express terms advocate the

63. In examining the governmental interests supporting restriction of independent expenditures, the Court stated:

The markedly greater burden on basic freedoms caused by [the independent expenditure limit] thus cannot be sustained simply by invoking the interest in maximiz-

ing the effectiveness of the less intrusive contribution limitations. . .

-.. We find that the governmental interest in preventing corruption and the

appearance of corruption is inadequate to justify [the] ceiling on independent expenditures.

424 U.S. at 44.45 (emphasis added).

This statement suggests that the Court did not find the prevention of corruption a substantial enough interest in and of itself for the independent expenditure ceiling to pass the first of the strict scrutiny standards. Such a conclusion cannot be justified since the Court found the same governmental purpose to be sufficient in the context of candidate contribution limits. The Court's reasoning here can be reconciled with its previous analysis if the passage is read to mean that the limit on independent expenditures "inadequately" promotes the substantial interest in preventing corruption because, as is demonstrated in the opinion, it fails the second and third strict scrutiny stages.

64. Id. at 25.

65. Id. at 46 n.53.

66. Id. at 46 .

67. Id. at 47 .

68. Id. 
election or defeat of a clearly identified candidate." 60 Redefined in this manner, the ceiling would not apply to messages of advocacy phrased in less explicit terms. The Court stated:

It would naively underestimate the ingenuity and resourcefulness of persons and groups desiring to buy influence to believe that they would have much difficulty devising expenditures that skirted the restriction on express advocacy of election or defeat but nevertheless benefited the candidate's campaign. ${ }^{70}$

The Court concluded that "no substantial societal interest would be served by a loophole-closing provision ... that permitted unscrupulous persons and organizations to expend unlimited sums of money in order to obtain improper influence over candidates for elective office."71

Because the independent expenditure limitations thus failed to focus directly and narrowly upon the government's interests, the Court declared the restriction unconstitutional. It did not, therefore, proceed to a consideration of other less intrusive means of "loophole closing."

\section{B. Donations and Strict Scrutiny}

Prior analysis established that donations implicate the fundamental First Amendment values of an individual's association with a political committee, his expression through the committee, and the committee's capacity for amplifying the speech of its members. As donations merit at least the constitutional protection afforded candidate contributions, regulation of donations must pass muster under the same strict scrutiny test which Buckley applied to both contributions and independent expenditures.

\section{Substantial Governmental Interests in Regulation}

Limitations upon donations reflect Congress's intent to mend the network of election reforms lacerated by repeal of the independent expenditure limitation. The legislative history of the 1976 Amendments indicates that the central interest underlying the limitations is that of the former independent expenditure provision. ${ }^{72}$ Ceilings upon

69. Id. at 44.

70. Id. at 45 .

71. Id.

72. The Joint Explanatory Statement of the Conference Committee on the 1976 Amendments asserted three rationales for ceilings upon donations:

[F]irst, these limits restrict the opportunity to circumvent the $\$ 1,000$ and $\$ 5,000$ limits on contributions to a candidate; second, these limits serve to assure that candidates' reports reveal the root source of the contributions the candidate has received; and third, these limitations minimize the adverse impact on the statutory 
donations are designed to restrict the opportunity to circumvent contribution limits through gifts to unauthorized committees. Conceivable examples of such evasion include donations to committees likely to contribute to a particular candidate, donations to "dummy" committees established and controlled by the donor, and donations directed to a particular candidate through intermediaries. To the extent that the objective of the donation limits is the prevention of actual or apparent corruption, the same substantial state purpose that supported limitations on contributions and independent expenditures ${ }^{73}$ supports regulation of donations.

\section{Direct and Narrow Focus}

The limitations do not survive, however, the second stage of Buckley's strict scrutiny, that regulation be narrowly drawn to achieve the government's ends.

The 1976 Amendments are radically overinclusive as a means of stemming actual and apparent corruption because they regulate the relationship between a political committee and its donors, and not the relationship between donors and the candidates benefited. This can be seen most clearly by considering political committees organized solely to make independent expenditures. ${ }^{74}$ The government's pur-

scheme caused by political committees that appear to be separate entities pursuing their own ends, but are actually a means for advancing a candidate's campaign.

H.R. REP. No. 1057, 94th Cong., 2d Sess. 31, 57.58 (1976), reprinted in [1976] U.S. CoDE Conc. \& AD. News 946, 972-73. The third rationale merely restates the first reason: the need to prevent evasion of the candidate contribution limitations. The second rationalereporting root sources-appears to have no logical connection to limits on donations. The 1976 Amendments and regulations include explicit disclosure requirements which serve this goal. See 2 U.S.C.A. $\$ 432$ (c) (West Cum. Supp. 1977) (requiring treasurer of political committee to record the identity of persons who contribute in excess of $\$ 50)$; id. $\$ 434$ (b) (requiring political committees and candidates to file periodic reports with the FEC disclosing the identity of all persons contributing more than \$100 within any calendar year); Regulation $\$ \S 102.9$, 104.2. The proffered purposes of the donation limitations, therefore, condense into a single objective: to close loopholes in the candidate contribution ceilings.

73. See pp. 962, 963-64 supra.

74. For example, a committee may be established only to pool the resources of individuals who anticipate placing newspaper advertisements that advocate the election or defeat of identified federal candidates. See note 39 supra. The FEC has explicitly interpreted the limitation on donations to include such donations to committees "making independent expenditures." Regulation $\$ 110.1$ (d).

FEC records demonstrate that independent spending committees channel substantial funds into the electoral campaign pipeline. During the 1976 elections, 38 committees spending in support of convention delegates and not authorized by any presidential candidate ("unauthorized delegate committees") and 39 committees making independent expenditures filed reports with the Commission disclosing their disbursements advocating the election or defeat of federal candidates. FEC, FEC Disclosure Series, No. 3: Index of Independent Expenditures by Individuals and Receipts and Expenditures by Un. 
pose in restricting donations to such committees must depend upon its interest in regulating the committees' eventual use of their funds, for the act of donating per se is certainly of no interest in the regulation of campaigns. Congress's primary concern is the possible corruptive influence of the committees' expenditures. But, as Buckley authoritatively pronounced, ${ }^{75}$ there is not a sufficient means-ends relation to justify limitation of independent expenditures by a person or a committee. There can, therefore, be no sufficient justification to limit donations that fund expenditures that cannot be constitutionally regulated. If a person's independent speech cannot be restricted constitutionally, neither can his speech through association. ${ }^{76}$

Even where political committees contribute to candidates, the focus upon the donor-committee relationship produces unconstitutional overbreadth. First, political committees themselves are restricted by candidate contribution ceilings. ${ }^{7}$ Thus, even if a particular donor were to give millions to a political committee, the actual corruptive potential of his donations could not exceed the potential permitted by limits on committee contributions to a candidate. Second, the appearance of corruption is ameliorated if a political committee has many donors; the recipient candidate, and the public at large, cannot determine with any certainty the individual source of the candidate's contribution from the committee. ${ }^{78}$ The political committee in effect

authorized Delegates, 1976 Campaign, at 3, 40-61 (March 1977) (on file with Yale Law Journal) (number of independent expending committees derived by examination of list of independent spenders, pp. 40-61). The unauthorized delegate committees reported donations of $\$ 305,462$ and expenditures of $\$ 295,613 . I d$. at 3. The independent expending committees reported $\$ 29,281$ of expenditures. Id. at 40-61 (calculated from figures listed). Of course, due to ignorance of reporting requirements, these figures may understate the total amount actually spent independently during the 1976 elections. They may also reflect a lower than desired level of spending due to the 1976 Amendments' limitations on donations. FEC data is not yet available for independent expenditures during the 1976 elections by active multicandidate committees and other committees contributing to candidates.

75. See pp. 964.65 supra.

76. For a general discussion of the unconstitutionality of limitations on donations to independently expending committees, see Testimony of John Bolton II before the Federal Election Commission on Proposed Regulations: Part 109 ("Independent Expenditures"), at 8.12 (June 9, 1976) (copy on file with Yale Law Journal) (appearing on behalf of the American Conservative Union and Mr. Stewart R. Mott); and Clagett \& Bolton, supra note 1 , at 1364-67.

77. 2 U.S.C.A. $\$ 441 \mathrm{a}(\mathrm{a})(1)$, (2) (West Cum. Supp. 1977).

78. The inability of candidates to identify the original sources of their contributions from political committees would appear to increase as the size of the contributing committces increases. Donors to multicandidate committees (which by definition have more than fifty donors, see note 8 supra) scem particularly well-insulated. As of February 9, 1977, 1377 active multicandidate political committes not established by a political party organization had filed reports with the FEC. Telephone Inteview with Susan Tifft, FEC Assistant Press Secretary (Feb. 9, 1977) (notes on file with Yale Law Journal). 
insulates its donors from actual or apparent quid pro quo arrangements with the candidate.

Admittedly, corruptive potential may inhere in contributions by a political committee that is totally or primarily the instrument of a single donor or an interest group composed of easily identifiable donors. But the limitations on donations prove underinclusive as a means of regulating this potential abuse. A donor could easily circumvent the ceiling on candidate contributions by giving funds to as many "dummy" committees as he could establish; these committees could then funnel his donations to the desired candidates. ${ }^{79}$ The 1976 Amendments' restrictions on donations to any one "dummy" committee do not prevent the actuality or appearance of electoral corruption. ${ }^{80}$ As the Buckley Court recognized, ceilings upon contributions alone do not foreclose evasion through proliferation of political committees under common control. ${ }^{81}$

Therefore, regulation of donations does not focus directly and narrowly on the government's interests in loophole-closing. Although, as Buckley determined, there is a substantial governmental interest in restricting the contributions of political committees to candidates, this interest cannot mechanically justify limitations upon donations.

\section{Less Intrusive Alternative Means}

The final test enunciated in Buckley requires an examination of less intrusive alternative means by which the government may achieve its objectives. Such means, in fact, already exist: several provisions of the Act and Federal Election Commission (FEC) rulings focus directly and narrowly upon circumvention of the candidate contribution limits. They construct a "cordon sanitaire" around the candidate, a legal bulwark against sham transactions, without intruding upon First Amendment liberties to the extent that those liberties are impinged upon by direct limits on donations.

Donations to a committee authorized by a candidate to accept contributions on his behalf are deemed "contributions made to such candidate," 82 and will apply against the donor's contribution limit

79. The $\$ 25,000$ ceiling upon an individual's annual contributions, 2 U.S.C.A. $\$ 441$ a (a)(3) (West Cum. Supp. 1977), renders the ceiling on donations underinclusive only to the extent of $\$ 5,000$ donations to five committees, $\$ 1,000$ donations to 25 committees, or any similar variation. But see pp. $971-73$ infra.

80. Viewed as a whole, the Act operates to stem this abuse through the constructive contribution and nonproliferation provisions of the 1976 Amendments and the FEC regulations. See pp. 969-70 infra. The limits on donations by themselves, however, prove underinclusive in stemming the abuse that they were purportedly enacted to prevent.

81. 424 U.S. at 28 n.31.

82. 2 U.S.C.A. $\$ 441 a(a)(7)(A)$ (West Cum. Supp. 1977). 
with respect to the candidate..$^{83}$ Even if the recipient committee is not authorized by a candidate to receive contributions, any donations made "on behalf of a particular candidate" or "in any way earmarked or otherwise directed through an intermediary or conduit" will also be considered contributions to be applied against the donor's limitation with respect to the candidate. ${ }^{84}$ FEC regulations further bolster the candidate contribution limits. They permit a person to contribute the maximum directly to a candidate and to donate to committees likely to support that candidate only if (1) the committees are not authorized by the candidate or do not contribute solely to that candidate; (2) the donor does not give with the knowledge that a substantial portion of his donations will be contributed to that candidate; or (3) the donor does not otherwise retain control over the funds given..$^{85}$

The Act also attempts to thwart opportunities for abuse arising from political committee expenditures that appear independent but are actually coordinated with a candidate's campaign. Any expenditure by a person made "in cooperation, consultation, or concert, with, or at the request or suggestion of" the candidate, his authorized committees or agents, constitutes a contribution to the candidate ${ }^{86}$ to be applied against that person's contribution limit.st

83. See id. $\S 441 a(a)(1)(A),(2)(A) ;$ Regulation $\$ \$ 110.1(a)(1), 110.2(a)(1)$. The statute does not explicitly refer to donations made to political committees authorized to make expenditures on behalf of a particular candidate. The FEC regulations define such a committee as an "authorized committec." See id. $\$ 100.14(\mathrm{~b})(1)$. Hence, donations to these committees presumably would also come within the $\$ 1,000$ or $\$ 5,000$ candidate contribution ceilings. A contrary conclusion would permit a person to evade his candidate contribution limit by funding the activities performed by a committee on that candidate's behalf.

Donations to a candidate's authorized expending committee may also come with the purview of 2 U.S.C.A. $\$ 441 a(a)(8)$ (West Cum. Supp. 1977), which treats funds directed to a candidate through an "intermediary or conduit" as a contribution to the candidate.

84. 2 U.S.C.A. $\$ 441 a(a)(8)$ (West Cum. Supp. 1977); see Regulation $\S 110.6$. The regulations define "earmarked" as "a designation, instruction, or encumbrance (including those which are direct or indirect, express or implied, oral or written) which results in all or part of a contribution or expenditure being made to, or expended on behalf of, a clearly identified candidate or a candidate's authorized committee." $I d$. $\$ 110.6(\mathrm{~b})$.

85. Regulation $\$ 110.1(\mathrm{~h})$. It may be argued that a flat limit on donations, even if overbroad, may be enforced more easily than the "indirect," "earmarked," and "constructive" contribution provisions requiring analysis of contributor-candidate relations. But the FEC will face the same enforcement difficulties, even with donation ceilings, because the other provisions are necessary to make effective the candidate contribution limits. Even if the donation limits curb significant evasion, this alone cannot justify the heavy burden that regulation of donations places upon vital speech and association with political committees. Cf. United States v. National Comm. for Impeachment, 469 F.2d 1135, 1141-42 (2d Cir. 1972) (First Amendment requires a narrow construction of "expenditure" and "contribution" under 1971 Federal Election Campaign Act, a construction which admittedly impedes enforcement).

86. 2 U.S.C.A. $\$ 441 \mathrm{a}(\mathrm{a})(7)$ (B)(i) (West Cum. Supp. 1977); see Regulation $\$ 109.1$ (a), (c).

87. 2 U.S.C.A. $\$ 441 \mathrm{la}(\mathrm{a})(1)(\mathrm{A}),(2)(\mathrm{A})$ (West Cum. Supp. 1977), see Regulations $\$ \$ 110.1$ (a)(1), 110.2(a)(1). 
Finally, the 1976 Amendments contain "nonproliferation" provisions. These prevent evasion of the candidate contribution ceilings by persons who create multiple "dummy" committees through which contributions can be directed to a particular candidate. For purposes of the candidate contribution limitations, all political committees "established or financed or maintained or controlled" by the same corporation, labor organization or any other person (including all parent, subsidiaries, branches, divisions or departments or local units) are considered a single political committee entitled to contribute only $\$ 1,000$ or $\$ 5,000$ to a federal candidate. For example, where $\mathrm{X}$ creates and controls committees $\mathrm{A}, \mathrm{B}$, and $\mathrm{C}$ and donates $\$ 5,000$ to each, the committees together can contribute only $\$ 1,000$ to a particular candidate. ${ }^{88}$ For organizations not specified in the statute, the FEC has developed indicia to determine whether a political committee is established, financed, maintained or controlled by a single individual or organization. ${ }^{89}$

88. 2 U.S.C.A. $\$ 441 \mathrm{a}(\mathrm{a})(5)$ (West Cum. Supp. 1977); see Regulation $\$ 100.3$.

Proliferation of political committees as a device for evasion had been recognized as a significant problem by the FEC in its early rulemaking. In Advisory Opinion 1975-45, 40 Fed. Reg. 53722 (1975), the Commission held that the multicandidate committecs established, funded, and staffed by the Agricultural and Dairy Educational Political Trust could not be regarded as exercising independent judgment in the selection of federal candidates to whom they would contribute, and would therefore be treated as one political committee for limitation purposes.

89. Regulation $\$ 110.3(\mathrm{a})(\mathrm{1})$ (iii). Indicia include:

(A) Ownership of a controlling interest in voting shares or securities;

(B) Provisions of by-law's, constitutions, or other documents by which one entity has the authority, power, or ability to direct another entity;

(C) The authority, power, or ability to hire, appoint, discipline, discharge, demote, or remove or otherwise influence the decision of the officers or members of an entity;

(D) Similar patterns of contributions;

(E) The transfer of funds between committees which represent a substantial portion of the funds of either the transferor or transferee committee, other than the transfer of funds between the committees which jointly raised the funds so transferred.

The proliferation of national, state and subordinate party committees is dealt with separately in the 1976 Amendments. See 2 U.S.C.A. $\$ 441$ (a)(5)(B) (West Cum. Supp. 1977); Regulation $\$ 110.3(b)$. Concern over proliferation of party committees is particularly grave because party associations are subject to more liberal limits on expenditures coordinated with party candidates. See 2 U.S.C.A. $\$ 441$ (d) (West Cum. Supp. 1977); Regulation $\$$ 110.7; FEC Opinion of Counsel to Congressman Michael T. Blouin (March 19, 1976) (copy on file with Yale Law Journal).

To mitigate this problem, the FEC regulations treat the national party committee and any political committees "established, financed, maintained and controlled" by it as a single political committec, Regulation $\S 110.3(\mathrm{~b})(1)$; and a state party committee and all local, county, district or regional party committees that have been "established, financed, maintained or controlled" by it are considered as a single political committec. Id. $\$ 110.3(\mathrm{~b})(2)$ (ii). "Established, financed, maintained or controlled" would be construed as meeting any or all of the indicia noted above. The presumption of operation as a single political committee may be rebutted for a subordinate state party committee if 
Thus, the "cordon sanitaire" appears effectively to ensure the integrity of the candidate contribution restrictions without impermissibly abridging a donor's rights of expression through, and association with, a political committee. Because these provisions regulate the relationship between donors or committees and the recipient candidate, the "cordon sanitaire" does not suffer from the same overbreadth as the limits on donations. In addition, the "cordon sanitaire" does not prove underinclusive, as it focuses on transactions that carry the potential for actual or apparent corruption. The 1976 Amendments' limitations on donations fulfill no essential function in siemming evasion of the candidate contribution ceilings and, therefore, cannot survive the last stage of Buckley's strict scrutiny test.

\section{Limitation of Total Contributions and Strict Scrutiny}

The 1976 Amendments reenact verbatim the 1974 Amendments' restriction on total annual contributions made by an individual..$^{90}$ As donations clearly fall within the Act's definition of "contribution," 91 an individual's donations must be applied against his $\$ 25,000$ ceiling. In light of the analysis in Buckley, this new reach of the aggregate limit raises serious questions as to its constitutionality.

Buckley had sustained the restriction in the 1974 Amendments. The Court found that it functioned as a loophole-closing device:

[T]his quite modest restraint upon protected political activity serves to prevent evasion of the $\$ 1,000$ contribution limitation by a person who might otherwise contribute massive amounts of money to a particular candidate through the use of unearmarked contributions to political committees likely to contribute to that candidate, or huge contributions to the candidate's political party. ${ }^{92}$

While the $\$ 1,000$ and $\$ 5,000$ ceilings on candidate contributions were interpreted to encompass "direct," 93 "earmarked," 94 and "coordi-

(i) it receives no funds from any party unit other than its own state party committee, and (ii) it does not contribute in cooperation, consultation or in concert with, or at the request or suggestion of, any other party unit. Id. $\$ 110.3(\mathrm{~b})(2)(\mathrm{ii})(\mathrm{A}),(\mathrm{B})$.

90. Compare 18 U.S.C. $\$$ 608(b)(3) (Supp. V 1975) (repealed 1976) with 2 U.S.C.A. $\S 441 a(a)(3)$ (West Cum. Supp. 1977).

91. 2 U.S.C.A. $\$ 431$ (c) (West Cum. Supp. 1977).

92. 424 U.S. at 38.

93. 18 U.S.C. $\$ 608(b)(1)$ (Supp. $V$ 1975) (repealed 1976; reenacted in 2 U.S.C.A. $\$ 441 a$ (a)(I)(A), (2)(A), (7)(A) (West Cum. Supp. 1977)).

94. 18 U.S.C. $\$ 608(b)(6)$ (Supp. V 1975) (repealed 1976; reenacted in 2 U.S.C.A. $\$ 441 a$ (a)(8) (West Cum. Supp. 1977)). 
nated"95 contributions, the ceilings did not deal explicitly with the opportunity for abuse inherent in large unearmarked contributions. Apparently, therefore, the Court regarded the $\$ 25,000$ ceiling as an inoffensive global limitation upon these contributions unrestricted elsewhere in the Act. So construed, the $\$ 25,000$ ceiling was "thus no more than a corollary of the basic individual contribution limitation [which had been] found to be constitutionally valid." 96

The reenactment of the $\$ 25,000$ limit in the 1976 Amendments, accompanied by the restrictions on "contributions" to political committees, creates constitutional difficulties which were not present before the Buckley Court. To the extent that the $\$ 25,000$ ceiling includes donations that cannot be considered contributions to a particular candidate, the reenacted provision suffers from the same overbreadth as the limitations on donations themselves. ${ }^{97}$ Furthermore, even if the provisions limited only candidate contributions, the 1976 Amendments and FEC regulations provide less restrictive means to serve the very governmental purpose which the Court identified in upholding the $\$ 25,000$ limit. ${ }^{8}$

The $\$ 25,000$ ceiling, therefore, cannot be adequately justified as a

95. 424 U.S. at 46-47. See p. 964 supra.

96. 424 U.S. at 38 .

97. See pp. 966-68 supra. It might be argued that, if limitations on donations were held unconstitutional, donations should still be restricted to $\$ 25,000$ per year to stem the appearance of corruption fostered by the funneling of massive amounts of money to political committees. Such an appearance could arise, for example, if a generous contributor to the national party committee were appointed to an ambassadorship by the recently elected president.

This rationale fails, however, for precisely the same reason that the Buckley Court invalidated the limit on independent expenditures. The donor's gift, to be excluded from the $\$ 1,000$ contribution ceiling, must not have been coordinated with or controlled by the successful presidential candidate. Any appearance of corruption in the above hypothetical derives from a generalized identity of interest between the donor and the candidate (e.g., party affiliation), and not from any special contributor-candidate relationship. Such a generalized identity of interests exists whenever an individual donates to a cause-the NAACP or pro-life movement, for example-which the candidate also supports. In striking down the limitation of the 1974 Act on independent expenditures, the Buckley Court specifically found that the appearance of corruption stemming from such generalized identity of interests was not sufficient to justify the curtailment of First Amendment activities. Even in the case of a spender who actively advocates the election of a candidate, the Court noted that "[ $t]$ he absence of prearrangement and coordination of an expenditure with the candidate or his agent not only undermines the value of the expenditure to the candidate, but also alleviates the danger that expenditures will be given as a quid pro quo for improper commitments from the candidate." 424 U.S. at 47 . The Court concluded that the independent expenditure limit "thus fails to serve any substantial governmental interest in stemming the reality or appearance of corruption." Id. at 47-48. Thus, under the Buckley reasoning, no cognizable appearance of corruption would be created by donations that do not constitute contributions to federal candidates.

98. See pp. 968-70 supra. 
device to close loopholes in the candidate contribution limitations. Arguably, however, the annual limit serves a governmental interest different than that identified by the Buckley Court: it might purport to reduce an individual's total impact on the political process through candidate contributions, rather than his impact upon any particular candidate. This interest could accord with the purpose of the Act, as found by Buckley, to stem the actuality or appearance of corruption. ${ }^{99}$ For example, the restriction prevents contributors from selecting and supporting an indefinite number of "bloc" candidates (e.g., all pro-big business Republican or pro-labor Democratic candidates). Were the Court to find such a purpose, the $\$ 25,000$ limit would not be underinclusive; nor could it be replaced by equally effective but less intrusive regulations. The provision defines by its ceiling its desired effect and brings all corruptive influence within its reach.

But, even with this redefined purpose, the $\$ 25,000$ ceiling would be radically overinclusive with respect to donations, since not all donations can be classified as candidate contributions. This provision, like the other contribution limits, must focus upon the relationship between contributors and candidates, not on that between donors and political committees. For this provision to survive Buckley's strict scrutiny analysis, the terms of its regulation must directly and narrowly promote the government's redefined interest. Hence, the $\$ 25,000$ limit must be construed to restrict only donations that fall within the Act's or FEC regulations' criteria for direct, indirect or constructive contributions to a candidate..$^{100}$

\section{Conclusion}

Vital political expression and association, accorded the strongest constitutional protection in Buckley, cannot be suppressed in the service of administrative efficiency. Even though the government's purpose in regulation is weighty, that purpose cannot be pursued by means that broadly stifle fundamental personal liberties. Because donations are not inherently corruptive, because their restriction does not directly advance the government's interests, and because other measures are more closely tailored to correct evasion of contribution ceilings, the 1976 Amendments' limitations on donations are unconstitutional.

99. See p. 962 \& note 51 supra.

100. See pp. 968-69 supra. 